\title{
Teaching English allomorphs through 'Harry Potter and the Chamber of Secret' movie
}

\author{
1 Asfi Aniuranti*, 2'Tono Suwartono \\ ${ }^{1}$ Department of English Language Teaching, Universitas Nahdlatul Ulama Purwokerto, \\ Indonesia, \\ ${ }^{2}$ Department of English Language Teaching, Universitas Muhammadiyah Purwokerto, \\ Indonesia \\ *Corresponding Author \\ Email: a.aniuranti@unupurwokerto.ac.id
}

\begin{abstract}
The study is primarily concerned with the use of 'Harry Potter and the Chamber of Secret' to teach English allomorphs in EFL classrooms. This paper is an alternative way to teach them as a significant element of pronunciation. The types examined are Regular Past Tense, Regular Plural Number, Third Person Present, The Regular Possessive, and Reduced IS and HAS. Besides the main highlight of allomorph pronunciation, the movie also contemplates some suprasegmental features called word stress and sentence intonation. The teachers may also utilize the movie through four phases. They are warm-up activity, completion, categorization, and production. Bringing a movie that has many benefits into EFL classrooms may lead to a good comprehension of English allomorphs to the students.
\end{abstract}

Keywords: EFL classroom; pronunciation; English allomorphs; suprasegmental features; movie

Received:

16 May 2019
Revised:

21 February 2020
Accepted:

7 August 2020
Published:

31 August 2020

\section{INTRODUCTION}

The significance of pronunciation in every EFL classroom is undeniable. English pronunciation teaching makes the students familiar with the sounds and sounds feature and enhance their speaking skill. Teaching sounds give the students additional knowledge about spoken language and support them to boost their understanding and accuracy (Harmer, 2002). Understanding learners with good pronunciation even they make faults in some other aspects is easier than understanding learners whose pronunciation is hard to comprehend even they have excellent grammar (Fact sheet - What is pronunciation?, 2002). Furthermore, learners with bad pronunciation might feel less confidence, and this condition normally effects their personalities (AlAhdal, 2020). In short, pronunciation is totally important for the learners.

Although the pronunciation is an essential element in English, teaching pronunciation is perhaps fairly neglected. Pronunciation has been neglected for years in communicative approach (Tabandeh, Moinzadeh, \& Barati, 2019). 
Aniuranti, A., \& Suwartono, T. (2020). Teaching English allomorphs through 'Harry Potter and the Chamber of Secret' movie. EduLite: Journal of English Education, Literature, and Culture, 5 (2), 192-201. DOI: http://dx.doi.org/10.30659/e.5.2.192-201

Moreover, almost all English teachers who focus on teaching grammar and vocabulary, often abandon or avoid teaching pronunciation. Perhaps, they worry about teaching sounds and intonation; probably they think they have too many duties, and pronunciation teaching will only create things worse (Harmer, 2002). The abandonment of pronunciation teaching practice may be due to the clear complexness of English pronunciation and a misconception of the most suitable content of pronunciation teaching, and the best ways to teach that (Suwartono, 2014).

The neglect of teaching pronunciation probably has triggered some problems for students to comprehend pronunciation well. Mastering pronunciation is such a great challenge, especially for language learners who are not native speakers of English (ESL/EFL). After years of learning English, many learners of English as a second language have "great difficulties" in pronunciation (Gilakjani \& Ahmadi, 2011).

Regarding the importance of pronunciation in EFL classrooms, all English teachers have to comprehend and implement effective ways to teach pronunciation and its elements. One of the essential elements in pronunciation is allomorphs. Allomorph is a predictable variation of a morpheme (Brinton \& Brinton, 2010, p. 90; Jeffries, 2006, p. 75). Many English morphemes have two or more distinct pronunciations, called allomorphs, and the choice among them is defined by the contexts (Carstrairs-McCarthy, 2002). In short, allomorph is a predictable variation of a morpheme in which its pronunciation is defined by a certain context.

English itself has several types of allomorphs, for example, regular past tense, regular plural number, third person present, the regular possessive, and reduced IS and HAS. Based on the writers' experience, many Indonesian students even university students still struggle for pronouncing those allomorphs properly. For instance: (1) They played football last week; (2) She likes ice cream; and (3) Tom's already had three pens.

In the first example, most of the students commonly pronounce the word played as /plejed/ instead of /pleid/. They do not know the three variations of $\{-\mathrm{ed}\}$ morpheme. In the second example, the students also commonly say /larks/ instead of /larkz/ for the word likes. Many of them do not realize suffix $\{-s\}$ might be pronounced in three different ways. They are $/ \mathrm{s} /, / \mathrm{z} /$ and $/ \mathrm{Iz} /$. In the third one, many students normally pronounce /toms / instead of /tomz/ for (Tom's or Tom has), and they also pronounce /pens/ instead of / penz/ for the word pens. The students do not realize the variants of reduced HAS and regular plural number.

Being proficient in pronouncing allomorphs is a challenging matter for many English students. They have to comprehend certain contexts to produce the allomorphs properly. An English teacher as a class facilitator has to decide the right way to teach them. Teachers with all their efforts and main roles as the classroom director, manager, counselor, and a model in language use, have to facilitate learning inside the classroom and, probably extended to, outside formal learning context (Suwartono \& Aniuranti, 2018). All English teachers have a crucial duty in helping the students to be proficient in English (Yulia \& Budiharti, 2019). 
One of the recommended ways to teach allomorphs is by using English movies. They are proposed because they have many advantages. Firstly, movies can be utilized as media to motivate and entertain students. The usage of movies enables us to entertain and encourage students who have different skill levels (Ruusunen, 2010). Secondly, movies provide exposure to more natural English. Bringing movies in EFL classes gives real-life language input to the learners (Brown, 2010; Goctu, 2017; Ruusunen, 2011). Thirdly, movies provide fascinating visuals that assist the students to get a good understanding of the language. Movies have rich visuals that are helpful to boost students' learning skills or create positive learning experiences (Brown, 2010; Goctu, 2017). Fourthly, movie can be accessed easily. There are many movies available on internet or television (Ismail \& Moriyanti, 2019). In conclusion, English movies are suitable media to be implemented in teaching language skills or components like allomorphs.

A recommended English movie for teaching allomorphs is Harry Potter and the Chamber of Secrets. This movie was chosen for two reasons. Firstly, the movie contains many utterances using allomorphs, and they are well pronounced. Secondly, the writers assume that the students are going to love the movie because it is a very well-known movie. The movie can motivate the students as well as make them enjoy learning English. Playing the whole movie in a class will take much time, so the writers only discuss the way to utilize a scene/dialogue to teach allomorphs.

This study investigates five types of allomorphs in English. They are regular past tense, regular plural number, third person present, regular possessive, and reduced IS and HAS. Regular past tense verbs, morpheme \{ed\}, has three types of allomorphs. They are /t/, /d/ and /Id/. The choice of those three variations depends on the last sound of a word (Kreidler, 2004, p. 124; Lems, Miller \& Soro, 2010. p. 116). Regular plural number, third person present, regular possessive, and reduced IS and HAS have the same allomorphs. They are $/ \mathrm{s} /, / \mathrm{z} /$ or $/ \mathrm{Iz} /$, and the choice of those variants depends on the last sound of a word (Kreidler, 2010).

Besides the main discussion of the previous types of allomorphs, this research is also concerned with the suprasegmental features called word stress and intonation. These two features are very essential for English learners. Enhancing the pronunciation of English suprasegmental features can accommodate communication, boost self-esteem, and perhaps guide to a better future for the learners. Therefore, within the context of oral English communication, suprasegmental features has to be underlined or, at least, balanced (Suwartono, 2014).

Word stress is the height given to certain syllables within words and to specific syllables or words within sentences (Fact sheet - What is pronunciation?, 2002). A stressed syllable is pronounced with a greater amount of energy than an unstressed syllable, and it is more prominent in the flow of speech (Ladefoged \& Johnson, 2011). The stress of a polysyllabic word may be on the first syllable ('cannibal), the second (a'rena), the third (after'noon), or some later syllable. In short, English has various stress of word (Kreidler, 2010). 
Aniuranti, A., \& Suwartono, T. (2020). Teaching English allomorphs through 'Harry Potter and the Chamber of Secret' movie. EduLite: Journal of English Education, Literature, and Culture, 5 (2), 192-201. DOI: http://dx.doi.org/10.30659/e.5.2.192-201

Besides words stress, there is also intonation. Intonation is part of the language system. Human beings create melodies by changing the vibration frequency of the vocal cords, and most of them are at the accented syllable (Kreidler, 2010). In English, there are five major patterns of tones identified. They are fall, rise, fall-rise, rise-fall, and level.

\section{METHOD}

This study is intended to provide an alternative way to teach English allomorphs and suprasegmental features called word stress and sentence intonation. Those two essential elements in pronunciation are taught through 'Harry Potter and the Chamber of Secret' movie. In short, the method employed was descriptive qualitative since this article was written based on several theories and writers' analysis.

There were several phases in writing this paper. The first step was searching the relevant theories about English allomorphs, suprasegmental features, and the use of English movies in EFL classrooms. Those theories were used to consider the right movie and the best teaching stages. The second stage was choosing the right movie to teach allomorphs and suprasegmental features. The last was developing and expressing ideas in using the chosen movie by providing some possible teaching stages.

\section{RESULTS AND DISCUSSION}

\section{Teaching Stages}

There are four possible phases in employing the movie. Here is a brief explanation.

\section{Warm-up activity}

The teachers may do a warm-up to engage students' attention. This phase is fairly crucial in every teaching and learning process. Kay explains that warmups are different types of activities that assist the students to begin to think in English, review the previous materials, and become interested in the subject (Velandia, 2008). If a lesson starts with a warm-up, it will become enjoyable and fascinating (Estalkhbjari \& Khodareza, 2012).

In this study, the teachers may display some pictures related to the Harry Potter movie series, then ask several questions dealing with these series. The questions then become more specific in the movie 'Harry Potter and the Chamber of Secret'. The questions addressed might be some light questions such as Have you ever watched that movie? Do you like that? Why do you like it? Why don't you like it? Can you tell me the content of the movie? and so on.

\section{Completing}

After a warm-up activity, the teachers may distribute the prepared dialogue of the movie and ask the students to watch the movie while completing the dialogue. In Harry Potter and the Chamber of Secret, many parts or scenes can be implemented to teach the allomorphs. Here is an example. 


\section{Watch the following scene of the film then fill in the blanks. Location: Hogwarts - Flooded Corridor - Night}

Harry
Ron
Hermione
Harry
Others
Madame Pomfrey
Draco
Filch
Harry
Filch
Dumbledore
Others
Dumbledore
Prof. Lockhart
Dumbledore
Filch
Harry
Filch
Snape

Prof. Lockhart

Hermione

Snape

Harry

Dumbledore

Filch

Dumbledore
: Strange. I've never seen act like that.

: I don't like

: The Chamber of secrets has been

(2) that?

\section{blood.}

: Oh, no... (3) of the heir...beware.' It's written in

(4) cat. It's Mrs. Norris.

: (mumble, mumble) Ahhh! What's that?

: Oh!

: ‘

Mudbloods!

(5) of the heir beware!' You'll be next

: What's going on 'ere? Go on make way, make way. Potter what are you...Mrs. Norris? You've .

: No. No.

: I'll kill ya...I'll kill ya

: Argus! Argus, I...Everyone will proceed to their immediately. Everyone...you three.

: Ravenclaws, follow me!

(8) not dead, Argus. She has been

(9).

: Ah, thought so. So unlucky I wasn't there. I know exactly the counter curse that could have spared her.

: But how she has been (10). I cannot say...

: Ask him. It's him wrote on the wall.

: It's not true sir, I swear. I never (11) done it. You saw what he

: Rubbish!

: If I might, Headmaster? Perhaps Potter and his were simple in the wrong place at the wrong time. However, the Potter at dinner. (14) are suspicious. I, for one,don't recall seeing

: I'm afraid (15) my doing, Severus. You see, Harry was helping me answer my fan mail.

: (16) why Ron and I went looking for him, Professor. We'd just found him when he said...

: Yes, Miss Granger?

: When I said I wasn't hungry. We were heading back to the common room when we found Mrs. Norris.

: Innocent until proven guilty, Severus

: My cat has been (17). I wanna see some punishment!

: We will be able to cure her, Argus. As understand it, Madam Sprout has a very healthy growth of Mandrakes. When (18), a potion will be made which will revive Mrs, Norris. And in the meantime, I strongly recommend caution...to all.

\section{Location: Hogwarts - Moving Staircase - Night}

Hermione

Harry

Hermione
Strange?

(19) a bot strange, isn't it?

You hear this voice, a voice only you can hear, and then Mrs. 
Aniuranti, A., \& Suwartono, T. (2020). Teaching English allomorphs through 'Harry Potter and the Chamber of Secret' movie. EduLite: Journal of English Education, Literature, and Culture, 5 (2), 192-201. DOI: http://dx.doi.org/10.30659/e.5.2.192-201

$\begin{array}{ll}\text { Harry } & \text { Norris } \\ & \text { : Do you think I should have told them? Dumbledore and the } \\ \text { others, I mean? } & \text { : Are you mad? } \\ \text { Ron } & : \text { No, Harry. Even in the wizarding world, hearing } \\ \text { Hermonie } & \text { isn't a good sign. }\end{array}$

Picture

(22) right, you know.

\section{Categorization}

After completing the dialogue from the movie, the students have to categorize the types of allomorphs into five categories called regular past tense, regular plural number, third singular present, the regular possessive, or reduced IS or HAS. The students have to identify the sound that appears in each allomorph, the word stress, and sentence intonation.

\section{Production}

After categorizing the allomorphs from the dialogue, the teachers then ask the students to do a practice. They have to pronounce the allomorphs in the dialogue. They also need to pay attention to the word stress and sentence intonation.

\section{The Result}

The missing words in the dialog should appear as follows:

1. Spiders

2. Spiders

3. opened; enemies

4. Filch's

5. Enemies

6. Murdered

7. Dormitories

8. She's

9. Petrified

10. Petrified

11. who's

12. touched

13. friends

14. circumstances

15. that's

16. That's

17. Petrified

18. Matured

19. It's

20. turns up petrified

21 . voices

22. She's

The aforementioned missing words can be classified into several types of allomorphs. The detailed classification is displayed in the following table. 
Table 1. Types of allomorphs

\begin{tabular}{|c|c|c|c|c|}
\hline $\begin{array}{c}\text { Regular } \\
\text { Past Tense }\end{array}$ & $\begin{array}{l}\text { Regular Plural } \\
\text { Number }\end{array}$ & $\begin{array}{c}\text { Third } \\
\text { Singular } \\
\text { Present }\end{array}$ & $\begin{array}{l}\text { The Regular } \\
\text { Possessive }\end{array}$ & $\begin{array}{c}\text { Reduced IS or } \\
\text { HAS }\end{array}$ \\
\hline $\begin{array}{l}\text { opened } \\
\text { murdered } \\
\text { petrified } \\
\text { touched } \\
\text { matured }\end{array}$ & $\begin{array}{l}\text { spiders } \\
\text { enemies } \\
\text { dormitories } \\
\text { friends } \\
\text { circumstances } \\
\text { voices }\end{array}$ & turns up & Filch's & $\begin{array}{l}\text { what's (what is) } \\
\text { she's (she is) } \\
\text { who's (who has) } \\
\text { that's (that is) } \\
\text { it's (it is) }\end{array}$ \\
\hline
\end{tabular}

Here is the complete categorization of the allomorphs above:

Table 2. Complete analysis

\begin{tabular}{|c|c|c|c|c|}
\hline No & Sentence & $\begin{array}{c}\text { The } \\
\text { pronunciation } \\
\text { of the } \\
\text { Allomorphs }\end{array}$ & $\begin{array}{c}\text { Word } \\
\text { Stress }\end{array}$ & $\begin{array}{l}\text { Sentence } \\
\text { Intonation }\end{array}$ \\
\hline 1 & $\begin{array}{l}\text { I've never seen } \\
\text { spiders act like that. }\end{array}$ & $/ z /$ & $\begin{array}{l}\text { first } \\
\text { syllable }\end{array}$ & $\begin{array}{l}\text { falling } \\
\text { pattern }\end{array}$ \\
\hline 2 & $\begin{array}{l}\text { I don't like spiders } \\
\text {... what's that? }\end{array}$ & $\begin{array}{l}/ z / \\
/ \mathrm{s} /\end{array}$ & $\begin{array}{l}\text { first } \\
\text { syllable; } \\
\text { first } \\
\text { syllable }\end{array}$ & rise-fall \\
\hline 3 & $\begin{array}{l}\text { The Chamber of } \\
\text { secrets has been } \\
\text { opened ... enemies } \\
\text { of the heir ... beware. }\end{array}$ & $\begin{array}{l}/ \mathrm{d} / \\
/ \mathrm{z} /\end{array}$ & $\begin{array}{l}\text { first } \\
\text { syllable; } \\
\text { first } \\
\text { syllable }\end{array}$ & $\begin{array}{l}\text { falling } \\
\text { pattern }\end{array}$ \\
\hline 4 & $\begin{array}{l}\text { Oh, no...It's Filch's } \\
\text { cat. }\end{array}$ & $\begin{array}{l}\text { /s/; } \\
/ \mathrm{iz} /\end{array}$ & $\begin{array}{l}\text { first } \\
\text { syllable; } \\
\text { first } \\
\text { syllable }\end{array}$ & rise-fall \\
\hline 5 & $\begin{array}{l}\text { 'Enemies of the heir } \\
\text { beware!' }\end{array}$ & $/ z /$ & $\begin{array}{l}\text { first } \\
\text { syllable }\end{array}$ & $\begin{array}{l}\text { rising } \\
\text { intonation } \\
\end{array}$ \\
\hline 6 & $\begin{array}{l}\text { You've...murdered } \\
\text { my cat. }\end{array}$ & $/ \mathrm{d} /$ & $\begin{array}{l}\text { first } \\
\text { syllable }\end{array}$ & rise-fall \\
\hline 7 & $\begin{array}{lr}\text { Argus! } & \text { Argus, } \\
\text { I....Everyone } & \text { will } \\
\text { proceed to } & \text { their } \\
\text { dormitories } & \\
\text { immediately. } & \\
\end{array}$ & $/ z /$ & $\begin{array}{l}\text { first } \\
\text { syllable }\end{array}$ & $\begin{array}{l}\text { falling } \\
\text { pattern }\end{array}$ \\
\hline 8 & $\begin{array}{l}\text { She's not dead, } \\
\text { Argus. }\end{array}$ & $|z|$ & $\begin{array}{l}\text { first } \\
\text { syllable }\end{array}$ & $\begin{array}{l}\text { rising } \\
\text { intonation }\end{array}$ \\
\hline 9 & $\begin{array}{l}\text { She has been } \\
\text { petrified. }\end{array}$ & $/ \mathrm{d} /$ & $\begin{array}{l}\text { first } \\
\text { syllable }\end{array}$ & $\begin{array}{l}\text { raising } \\
\text { intonation }\end{array}$ \\
\hline 10 & $\begin{array}{l}\text { But how she has } \\
\text { been petrified, I } \\
\text { cannot say... }\end{array}$ & $/ \mathrm{d} /$ & $\begin{array}{l}\text { first } \\
\text { syllable }\end{array}$ & $\begin{array}{l}\text { falling } \\
\text { pattern }\end{array}$ \\
\hline 11 & $\begin{array}{l}\text { It's him who's done } \\
\text { it. }\end{array}$ & $|z|$ & $\begin{array}{l}\text { first } \\
\text { syllable }\end{array}$ & $\begin{array}{l}\text { falling } \\
\text { pattern }\end{array}$ \\
\hline 12 & $\begin{array}{l}\text { I never touched Mrs, } \\
\text { Norris. }\end{array}$ & $/ \mathrm{t} /$ & $\begin{array}{l}\text { first } \\
\text { syllable }\end{array}$ & $\begin{array}{l}\text { falling } \\
\text { pattern }\end{array}$ \\
\hline 13 & $\begin{array}{l}\text { Perhaps Potter and } \\
\text { his friends were } \\
\text { simply in the wrong } \\
\text { place at the wrong } \\
\text { time. }\end{array}$ & $/ z /$ & $\begin{array}{l}\text { first } \\
\text { syllable }\end{array}$ & $\begin{array}{l}\text { falling } \\
\text { pattern }\end{array}$ \\
\hline
\end{tabular}


Aniuranti, A., \& Suwartono, T. (2020). Teaching English allomorphs through 'Harry Potter and the Chamber of Secret' movie. EduLite: Journal of English Education, Literature, and Culture, 5 (2), 192-201. DOI: http://dx.doi.org/10.30659/e.5.2.192-201

\begin{tabular}{|c|c|c|c|}
\hline 14 & $\begin{array}{ll}\text { However, } & \text { the } \\
\text { circumstances } & \text { are } \\
\text { suspicious. } & \end{array}$ & $\begin{array}{l}\text { first } \\
\text { syllable }\end{array}$ & $\begin{array}{l}\text { falling } \\
\text { pattern }\end{array}$ \\
\hline 15 & $\begin{array}{l}\text { I'm afraid that's my } \\
\text { doing Severus. }\end{array}$ & $\begin{array}{l}\text { first } \\
\text { syllable }\end{array}$ & fall-rise \\
\hline 16 & $\begin{array}{l}\text { That's why Ron and } \\
\text { I went looking for } \\
\text { him Professor. }\end{array}$ & $\begin{array}{l}\text { first } \\
\text { syllable }\end{array}$ & $\begin{array}{l}\text { falling } \\
\text { pattern }\end{array}$ \\
\hline 17 & $\begin{array}{l}\text { My cat has been } \\
\text { petrified. }\end{array}$ & $\begin{array}{l}\text { first } \\
\text { syllable }\end{array}$ & $\begin{array}{l}\text { falling } \\
\text { pattern }\end{array}$ \\
\hline 18 & $\begin{array}{l}\text { When matured, a } \\
\text { potion will be made } \\
\text { which will revive Mrs. } \\
\text { Norris. }\end{array}$ & $\begin{array}{l}\text { first } \\
\text { syllable }\end{array}$ & $\begin{array}{l}\text { falling } \\
\text { pattern }\end{array}$ \\
\hline 19 & $\begin{array}{l}\text { It's a bot strange, } \\
\text { isn't it? }\end{array}$ & $\begin{array}{l}\text { first } \\
\text { syllable }\end{array}$ & $\begin{array}{l}\text { raising } \\
\text { intonation }\end{array}$ \\
\hline 20 & $\begin{array}{l}\text { You hear this voice, a } \\
\text { voice only you can } \\
\text { hear, and then Mrs. } \\
\text { Norris turns up } \\
\text { petrified. }\end{array}$ & $\begin{array}{l}\text { first } \\
\text { syllable }\end{array}$ & $\begin{array}{l}\text { falling } \\
\text { pattern }\end{array}$ \\
\hline 21 & $\begin{array}{l}\text { No, Harry. Even in } \\
\text { the wizarding world, } \\
\text { hearing voices isn't a } \\
\text { good sign. }\end{array}$ & $\begin{array}{l}\text { first } \\
\text { syllable }\end{array}$ & $\begin{array}{l}\text { falling } \\
\text { pattern }\end{array}$ \\
\hline 22 & $\begin{array}{l}\text { She's right, you } \\
\text { know. }\end{array}$ & $\begin{array}{l}\text { first } \\
\text { syllable }\end{array}$ & $\begin{array}{l}\text { falling } \\
\text { pattern }\end{array}$ \\
\hline
\end{tabular}

The complete analysis reveals that all five types of allomorph emerge in the dialogue. The first type that appears is regular past tense allomorphs. They are /d/ (opened, murdered, petrified, and matured) and /t/ (touched). The second kind is the regular plural number that consists of / $z$ / (spiders, enemies, dormitories, and friends) and /Iz/ (circumstances and voices). The third type is person present allomorph in the form of $/ z /$ (turns up). The fourth type is regular possessive allomorph in the form of / Iz/ (Filch's). The fifth kind is reduced IS and HAS allomorphs. They consist of /s/ (what's, that's, and it's) and $/ z /$ (she's and who's). The analysis was completed by paying attention to the last sound of each word. The allomorph pronunciation is defined by the last phoneme of the word in which the suffix is added (Kreidler, 2010).

In short, the scene obviously can be employed to teach five kinds of allomorphs. The students may learn the complicated context in pronouncing the allomorph through the dialogue. While learning the context of using allomorphs, the students directly can also study the correct pronunciation of each word from the native speakers of English who acted in the movie. This fact is in line with the argument that movies might bring real-life language input in EFL classrooms (Brown, 2010; Goctu, 2017; Ruusunen, 2011).

For the word stress, all the words which consist of allomorphs are stressed on the first syllable even for words that consist of two or more syllables. It indicates that the addition of suffixes probably does not influence the stress pattern. English word stress itself is varied, but the movie might give the way of pronouncing each word with the correct stress. As stated by 
King using movies is an opportunity of being exposed to various native speaker voices, stress, accents, and dialects (Goctu, 2017).

For sentence intonation, four types appear in the dialogue. They are falling pattern, rising intonation, fall-rise, and rise-fall. The students might get an understanding of sentence intonation by watching the movie and paying attention to the way native speakers pronounce the sentences. Movies are a helpful way for students to practice and listen to authentic conversations and be exposed to various accents (Goctu, 2017; Suwartono, 2008).

\section{CONCLUSION}

Overall, an English movie entitled 'Harry Potter and the Chamber of Secret' can be utilized as a medium to teach allomorphs. The movie contains many helpful dialogues for learning allomorphs properly. Besides, the movie can be valued to teach suprasegmental features such as word stress and sentence intonation. The teachers may employ four phases in their classes. The stages are warm-up activity, completion, categorization, and production. The dialog discussed in this paper contains regular past tense, regular plural number, third person present, the regular possessive, and reduced IS and HAS allomorphs.

\section{ACKNOWLEDGEMENTS}

This study did not receive any specific grant from funding agency in the public, commercial, or not-for-profit sector.

\section{REFERENCES}

Al-Ahdal, A. A. (2020). Overcoming Pronunciation Hurdles in EFL Settings: An Evaluation of Podcasts as a Learning Tool at Qassim University Saudi Arabia. Asian EFL Journal, 27(1).

Brinton, L. J., \& Brinton, D. M. (2010). The Linguistics Structure of modern English. Amsterdam: John Benjamins Publishing Company.

Brown, S. K. (2010). Popular films in the EFL classrooms: Study of metodology. Procedia Social and Behavioral Science, 3, 45-54.

Carstrairs-McCarthy, A. (2002). An introduction to English morphology: Words and their structure. Edinburgh: Edinburgh University Press Ltd.

Estalkhbjari, Z. P., \& Khodareza, M. (2012). The effects of warm-up tasks on the Iranian EFL students' writing ability. International Education Studies, 5(2), 190-203. doi:10.5539/ies.v5n2p190

Fact sheet - What is pronunciation? (2002). (Department of Imigration of and Multicultural and Indigenous Affairs: Australia) 
Aniuranti, A., \& Suwartono, T. (2020). Teaching English allomorphs through 'Harry Potter and the Chamber of Secret' movie. EduLite: Journal of English Education, Literature, and Culture, 5 (2), 192-201. DOI: http://dx.doi.org/10.30659/e.5.2.192-201

Gilakjani, A. P., \& Ahmadi, M. R. (2011). Why is pronunciation so difficult to learn? English Language Teaching, 4(3), 74-83. doi:10.5539/elt.v4n3p74

Goctu, R. (2017). Using movies in EFL Classrooms. Eropean Journal of Language and Literature Studies, 3(2), 121-124.

Harmer, J. (2002). The practice of English language teaching. Edinburgh: Pearson Educational Limited.

Ismail, N. M., \& Moriyanti. (2019). The overview analysis of the movie sense and sensibility. Journal of English Education, Literature, and Culture (Edulite), 4(1), 45-54. doi:http://dx.doi.org/10_30659/e.4.1.45-54

Jeffries, L. (2006). Discovering language: The structure of modern English. New York: Palgrave Macmillan.

Kreidler, C. V. (2010). The pronunciation of English: A course book. Victoria: Blackwell Publishing.

Ladefoged, P., \& Johnson, K. (2011). A course in phonetics. Boston: Wadsworth Cengage Learning.

Lems, K., Miller, L. D., \& Soro, T. M. (2010). Teaching reading to English language learners. New York: The Guilford Press.

Ruusunen, V. (2010). Using movies in EFL teaching: the point of view of teachers (Master's thesis). University of Jyvaskyla, Department of Languages English.

Suwartono. (2008). Film conversation: Informalities and sound of naturalness. English Edu, 8(1), 20-38.

Suwartono, T. (2014). Enhancing the pronunciation of English suprasegmental features through reflective learning method. TEFLIN Journal, 25(1), 80-93.

Suwartono, T., \& Aniuranti, A. (2018). Digital teaching tool in 21st Century EFL classroom: Are our teachers ready? Journal of English Language, Literature, and Teaching, 3(2), 57-62.

Tabandeh, F., Moinzadeh, A., \& Barati, H. (2019). Differential Effects of FonF and FonFS on Learning. The Journal of Asia TEFL, 16(2), 499-515.

Velandia, R. (2008). The role of Warming up activities in adolescent students' involvement during the English class. Profile Journal, 10, 9-26.

Yulia, Y., \& Budiharti, F. R. (2019). HOTS in teachers classroom interaction: A case study. Journal of English Education, Literature, and Culture (Edulite), 4(2), 132-141. doi:http://dx.doi.org/10.30659/e.4.2.132-141. 